\title{
接触面を無塗装とした厚板・多列の 高カボルト摩擦接合継手のすべり耐力試験
}

\author{
村越 潤 ${ }^{1}$ 石原 $\quad 大$ 作 $^{2} \cdot$ 澤田 $\quad$ 守 $^{3} \cdot$ 山口 $\quad$ 隆司 ${ }^{4}$ \\ 1正会員（国研）土木研究所 構造物メンテナンス研究センター（†305-8516 茨城県つくば市南原1-6） \\ E-mail: murakosi@pwri.go.jp \\ 2正会員 (国研)土木研究所＼cjkstart構造物メンテナンス研究センター（テ305-8516 茨城県つくば市南原1-6） \\ E-mail: d-ishihara44@pwri.go.jp \\ 3正会員 国土交通省 中部地方整備局 企画部 企画課（广460-8514 名古屋市中区三の丸2-5-1） \\ E-mail: sawada-m85aa@mlit.go.jp \\ 4正会員 大阪市立大学大学院教授 工学研究科（干558-8585 大阪市住吉区杉本3-3-138） \\ E-mail: yamaguti@civil.eng.osaka-cu.ac.jp
}

部材の簡素化，構造の合理化を図った鋼橋の普及により厚板の部材が使用されるようになり，現場継手 部にも厚板・多列の高力ボルト摩擦接合継手が適用される場合がある。本検討では，接触面を無塗装とし た高力ボルト摩擦接合継手を対象としてすべり耐力試験を行い，母板厚やボルト列数等の構造諸元が，す ベり係数に与える影響について検討を行った。 母板厚を $50,75 \mathrm{~mm}$ と変化させ，ボルト列数を $3,8,12$ 列と

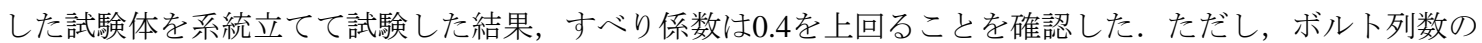
増加に伴い, すべり耐力時の母板と連結板間のずれ挙動が継手内において不均一となること, 8 列と 12 列の 試験体を比較した場合，母板厚 $50 \mathrm{~mm} ， 75 \mathrm{~mm}$ の場合ともに，すべり係数（平均值）が約 $3 \%$ 低下することが 確認された。

Key Words : high strength bolted friction type joint, slip resistance, thick plate, non-coated contact surface, number of rows of bolts

\section{1. はじめに}

公共事業におけるコスト縮減の観点から，工数低減の ために部材の簡素化，構造の合理化を図った鋼橋が普及 してきており，板厚 $50 \mathrm{~mm}$ を超える厚板鋼板も広く使用 されるようになっている. 鋼板の接合には，溶接継手と 高力ボルト摩擦接合継手の 2 種類が用いられているが, 高力ボルト摩擦接合継手の場合には，部材の厚板化によ り連結部のボルト列数が増加(多列化)する傾向にある.

ボルト継手の多列化がすべり耐力に及ぼす影響につい ては，厚板鋼板ではない場合も含めて，これまでにも各 種の調查研究が行われている. 例えば, 佐伯ら 1)，接触 面を無塗装とした母板厚 $35 \mathrm{~mm}$ の試験体を用いてすべり 耐力試験を実施し，ボルト列数の影響について検討を 行っており，その結果は，昭和 55 年の道路橋示方書・同 解説 II 鋼橋編 ${ }^{2)}$ (以下, 道示 II) 以降の解説に反映されて いる.すなわち，ボルト継手の連結長が長すぎるとボル 卜毎の分担摩擦力が著しく不均等になることを示し，ボ
ルト列数 12 列程度まではすべり耐力が低下しないとい う実験例もあるとした上で，ボルト列数は無理のない範 囲で 8列程度以下とするのがよいとしている. 近年では, 山口ら 3)が母板厚 50mm で F10T-M16 を使用した試験体を 用いてすべり耐力試験を行っている. ボルト列数 4, 8, 12 列を対象に多列化の影響について検討を行い，8列以 上の場合，4列と比較してすべり係数が低下するとして いる．以上のように，接触面を無塗装とした場合のボル 卜列数の影響に関するすべり耐力試験は行われているも のの事例は少なく，厚板で，かつ一般的に使用されてい るボルト（F10T-M22）を用いた試験例は報告されていな い.

一方，防食の観点から接触面に無機ジンクリッチペイ ントを塗装した場合についても，多列継手を対象とした すべり耐力試験によるすべり係数の検討が行われてい る 4) 7). 馬場ら 4) は, 母板厚 65mm で, ボルトの呼び M30の 太径ボルト継手の試験体を用いてすべり耐力試験を実施 している. ボルト列数 18 列までの試験結果より, すべり 
係数は 6 列から 12 列の間で $4 \%$ 程度低下寸るものの，18 列の場合では 12 列の場合を約 6\%上回っていることから， 多列となる場合にすべり係数が低下寸るとは一概にいえ ないとしている. 玉越ら りは，母板厚 $75 \mathrm{~mm}$ の厚板に対 して，M22のトルシア形超高力ボルトによる継手試験体 を用いてすべり耐力試験を実施し, ボルト列数が 12 列の 場合のすべり係数が，8列の場合に対して9\%程度下回る 結果が報告されている. 著者らのわは, 厚板へのボルト列 数 8 列を超える継手の適用性を把握するために, 母板厚 及びボルト列数をパラメータとした試験体のすべり耐力 試験を行い，ボルト列数 8 列に対して 12 列では，母板 厚 $75 \mathrm{~mm}$ の場合 $7 \% ， 50 \mathrm{~mm}$ の場合 $1 \%$ 低下寸る結果を得 ている. また，厚板・多列のボル卜継手に対する FEM解 析 6,8)により, すべり挙動を解析的に評価するとともに, 試験体と同一の継手に対してボルト列数が 8 列以上とな る場合，すべり係数が低下寸る傾向にあることを明らか にした.

これらの既往研究等をふまえ, 無機ジンクリッチペイ ントを塗装した場合の，8 列以上の場合のボルト継手と する場合のボルト許容力に乗じる低減係数が道示 II ${ }^{9)}$ 解 説では示された。一方，接触面を無塗装とした場合に対 しては，すべり耐力試験等による知見が必ずしも十分で ない。

著者らは，接触面を無塗装とした高力ボルト摩擦接合 継手を対象として，母板厚及びボルト列数をパラメータ とした試験体 (計 18 体) のすべり耐力試験を行い，無塗 装の場合におけるボルト列数が継手挙動に及ぼす影響に ついて検討を行った.

\section{2. 試験体}

\section{（1） 寸法形状と試験パラメータ}

本試験で用いた試験体の基本諸元を表-1に，その寸法 形状を図-1 に示す．母板厚は 50, $75 \mathrm{~mm} の 2$ 種類と，ボ ルト列数は $3 ， 8 ， 12$ 列の 3 種類として，それらを組み合 わせた 6 種類を試験対象とした. ここで試験体名称は「350A」のように表し，1番目の数字はボルト列数，2番目 は母板厚, 最後の記号は同一諸元の試験体 3 体を区別す る記号 (A,B,C) を示すこととする. ボルト列数は，施工 性や継手の適用実績を踏まえ, 概社上限に近いと考えら れる 12 列を最大とした. 試験体数は各 3 体とし, 試験体 の母板と連結板には溶接構造用圧延鋼材 SM490Y, 高力 ボルトにはF10T-M22を用いた. すべり耐力には, 式(1)で 表される母板の降伏耐力に対するす心゙り耐力の比率（以 下，すべり降伏耐力比）が影響することが明らかにされ ている ${ }^{10)}$. 本検討では，列数がすべり耐力に与える影響 について適切に評価できるように，すべり/降伏耐力比を 表-1＼cjkstart試験体の基本諸元

\begin{tabular}{|c|c|c|c|c|c|c|}
\hline $\begin{array}{l}\text { 試験体 } \\
\text { 名称 }\end{array}$ & $\begin{array}{l}\text { ボルト } \\
\text { 列数 }\end{array}$ & $\begin{array}{c}\text { 母板厚 } \\
\text { (mm) }\end{array}$ & $\begin{array}{c}\text { 連結板厚 } \\
\text { (mm) }\end{array}$ & $\begin{array}{c}\text { 母板幅 } \\
(\mathrm{mm})\end{array}$ & $\begin{array}{l}\text { 母板すべり } \\
\text { 耐力(kN) }\end{array}$ & \begin{tabular}{|c|} 
すべり \\
/降伏耐力比 \\
$\beta$
\end{tabular} \\
\hline 3-50A,B,C & 3 & \multirow{3}{*}{50} & \multirow{3}{*}{26} & 120 & 576 & 0.32 \\
\hline $8-50 \mathrm{~A}, \mathrm{~B}, \mathrm{C}$ & 8 & & & 190 & 1504 & 0.49 \\
\hline $12-50 \mathrm{~A}, \mathrm{~B}, \mathrm{C}$ & 12 & & & 270 & 2123 & 0.46 \\
\hline 3-75A,B,C & 3 & \multirow{3}{*}{75} & \multirow{3}{*}{38} & 120 & 584 & 0.22 \\
\hline $8-75 \mathrm{~A}, \mathrm{~B}, \mathrm{C}$ & 8 & & & 130 & 1527 & 0.51 \\
\hline $12-75 \mathrm{~A}, \mathrm{~B}, \mathrm{C}$ & 12 & & & 190 & 2104 & 0.45 \\
\hline
\end{tabular}

0.5 程度以下となるように試験体の板幅を設定した。

$$
\beta=\frac{\mu \cdot m \cdot n \cdot N}{(W-d) \cdot t \cdot \sigma_{Y}}
$$

ここに,

$\beta:$ すべり/降伏耐力比

$\mu:$ 設計すべり係数 $(=0.4)$

$m:$ 接合面の数 $(=2)$

$N$ : 設計ボルト軸力 $(\mathrm{kN})(=205 \mathrm{kN})$

$W$ : 母板の板幅 $(\mathrm{mm})$

$d:$ ボルト孔径 $(\mathrm{mm}) \quad(=24.5 \mathrm{~mm})$

$t:$ 母板の板厚 $(\mathrm{mm})$

$\sigma_{Y}:$ 母板の降伏点の公称值 $\left(\mathrm{N} / \mathrm{mm}^{2}\right)$

また，ボルト中心間隔は，ボルトが多列配置となる場 合，設計・施工の面から連結板をできるだけ小さく設計 することが一般的と考えられるため，M22の高力ボルト の最小中心間隔 $75 \mathrm{~mm}$ とした．なお，本試験で用いた試 験体は筆者らが文献 6)，7)で使用した試験体と同一の試 験体であり，接触面処理のみをブラスト処理に変更した ものである.

試験体組立て前に，母板及び連結板の板幅，板厚等を 計測した．板厚について，設計値に対する計測值の比率 の平均值は 1.003, 標準偏差は 0.01 で, 設計值とほぼ一致 しており，すべり耐力に影響を与えるような板厚差は生 じていなかった。試験体にボルト軸力を導入し, 組立て 後かつリラクゼーション計測前に母板と連結板の間の肌 すき量を試験体側面において計測した，肌すき量は，最 大で 0.16mm（試験体 12-50B）であった. 計測された肌す き量と，後述するすべり耐力試験で得られたすべり係数 の間の相関性は明確でなく，すべり耐力に有意な影響を 与えるものではなかったと考えられる.

\section{（2）材料強度特性}

表-2，表-3 に本試験で使用した鋼材及び高力ボルトの 機械的性質（ミルシート值）をそれぞれ示す。

\section{（3）表面処理}

接触面には ISO Sa 2.5 を目標としてブラスト処理（ス チールグリット：JSG5903 の粒度G50）を行った．参考 


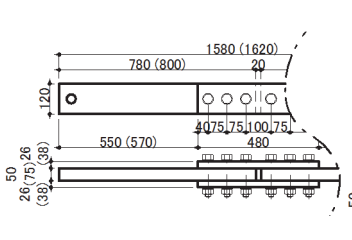

(a) 試験体 3-50（3-75）

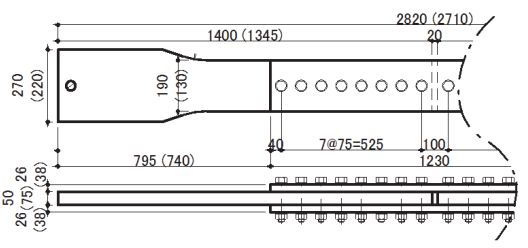

(b) 試験体 8-50（8-75）

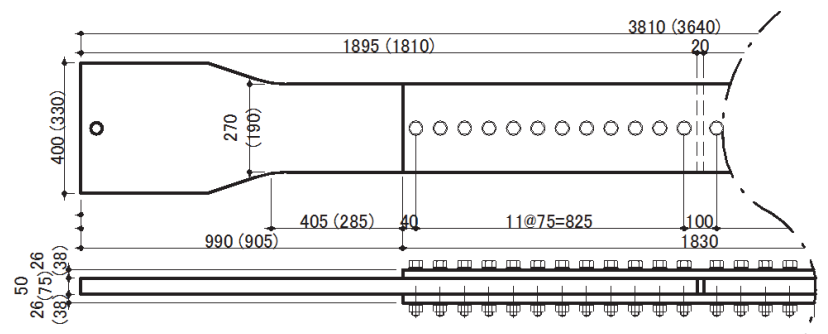

(c) 試験体 12-50（12-75）

図-1 試験体の寸法形状（単位：mm）

表-4 試験体の表面粗度 $R a(\mu m)$

\begin{tabular}{|c|c|c|c|c|}
\hline \multirow{2}{*}{$\begin{array}{c}\text { 試験体 } \\
\text { 名称 }\end{array}$} & \multicolumn{2}{|c|}{ 計測箇所 } & \multicolumn{2}{|c|}{ 平均値 } \\
\hline & $\begin{array}{c}\text { 母板 } \\
\text { (平均値) }\end{array}$ & $\begin{array}{c}\text { 連結板 } \\
\text { (平均值) }\end{array}$ & 試験体毎 & グループ毎 \\
\hline $3-50 \mathrm{~A}$ & 10.67 & 11.91 & 11.29 & \multirow{3}{*}{11.52} \\
\hline $3-50 \mathrm{~B}$ & 10.83 & 12.99 & 11.91 & \\
\hline $3-50 \mathrm{C}$ & 11.29 & 11.43 & 11.36 & \\
\hline $8-50 A$ & 10.72 & 10.69 & 10.70 & \multirow{3}{*}{10.98} \\
\hline $8-50 \mathrm{~B}$ & 10.95 & 11.43 & 11.19 & \\
\hline $8-50 \mathrm{C}$ & 10.81 & 11.28 & 11.05 & \\
\hline $12-50 \mathrm{~A}$ & 11.38 & 9.65 & 10.51 & \multirow{3}{*}{10.66} \\
\hline 12-50B & 10.19 & 11.27 & 10.73 & \\
\hline $12-50 \mathrm{C}$ & 11.04 & 10.42 & 10.73 & \\
\hline $3-75 \mathrm{~A}$ & 11.19 & 11.32 & 11.26 & \multirow{3}{*}{10.72} \\
\hline 3-75B & 10.01 & 9.92 & 9.97 & \\
\hline 3-75C & 10.65 & 11.22 & 10.93 & \\
\hline $8-75 \mathrm{~A}$ & 10.95 & 11.24 & 11.09 & \multirow{3}{*}{11.26} \\
\hline $8-75 \mathrm{~B}$ & 11.14 & 11.29 & 11.21 & \\
\hline $8-75 \mathrm{C}$ & 11.06 & 11.88 & 11.47 & \\
\hline $12-75 \mathrm{~A}$ & 12.57 & 10.95 & 11.76 & \multirow{3}{*}{11.21} \\
\hline $12-75 B$ & 11.64 & 10.92 & 11.28 & \\
\hline $12-75 \mathrm{C}$ & 11.04 & 10.13 & 10.58 & \\
\hline
\end{tabular}

表-2 鋼材の機械的性質

\begin{tabular}{|c|c|c|c|c|c|c|c|c|c|c|}
\hline \multirow[b]{2}{*}{ 鋼種 } & \multirow{2}{*}{$\begin{array}{l}\text { 使用 } \\
\text { 部位 }\end{array}$} & \multicolumn{4}{|c|}{ 機械的性質 } & \multicolumn{5}{|c|}{ 化学成分 (\%) } \\
\hline & & $\begin{array}{l}\text { 板厚 } \\
(\mathrm{mm})\end{array}$ & $\begin{array}{l}\text { 降伏点 } \\
\left(\mathrm{N} / \mathrm{mm}^{2}\right)\end{array}$ & $\begin{array}{l}\text { 引張強さ } \\
\left(\mathrm{N} / \mathrm{mm}^{2}\right)\end{array}$ & $\begin{array}{l}\text { 伸び } \\
\text { (\%) }\end{array}$ & $\mathrm{C}$ & $\mathrm{Si}$ & Mn & $P$ & S \\
\hline \multirow{4}{*}{ SM490YB } & \multirow{2}{*}{ 母板 } & 75 & 368 & 543 & 36 & 0.16 & 0.43 & 1.46 & 0.007 & 0.003 \\
\hline & & 50 & 431 & 566 & 27 & 0.16 & 0.43 & 1.46 & 0.007 & 0.003 \\
\hline & \multirow{2}{*}{ 連結板 } & 38 & 410 & 540 & 29 & 0.16 & 0.32 & 1.38 & 0.014 & 0.005 \\
\hline & & 26 & 437 & 563 & 27 & 0.17 & 0.32 & 1.38 & 0.013 & 0.004 \\
\hline
\end{tabular}

表-3 高力ボルトの機械的性質とトルク係数值

\begin{tabular}{|c|c|c|c|c|c|c|c|c|c|c|c|}
\hline \multirow{3}{*}{ 等級 } & \multirow{3}{*}{$\begin{array}{c}\text { ボルトの } \\
\text { 呼び }\end{array}$} & \multicolumn{7}{|c|}{ ボルト } & \multirow{3}{*}{$\begin{array}{l}\text { ナット } \\
\text { 製品 } \\
\text { 硬さ } \\
\text { HRC }\end{array}$} & \multirow{3}{*}{$\begin{array}{l}\text { 座金 } \\
\text { 製品 } \\
\text { 硬さ } \\
\text { HRC }\end{array}$} & \multirow{3}{*}{$\begin{array}{c}\text { トルク } \\
\text { 係数値の } \\
\text { 平均値 }\end{array}$} \\
\hline & & \multicolumn{5}{|c|}{ 4号試験片 } & \multicolumn{2}{|c|}{ 製品 } & & & \\
\hline & & $\begin{array}{c}\begin{array}{c}\text { 首下長さ } \\
(\mathrm{mm})\end{array} \\
\end{array}$ & $\begin{array}{c}\text { 有効断面積 } \\
\left(\mathrm{mm}^{2}\right)\end{array}$ & $\begin{array}{c}\begin{array}{c}\text { 耐力 } \\
\left(\mathrm{N} / \mathrm{mm}^{2}\right)\end{array} \\
\end{array}$ & $\begin{array}{c}\text { 引張強さ } \\
\left(\mathrm{N} / \mathrm{mm}^{2}\right) \\
\end{array}$ & 伸び(\%) & $\begin{array}{c}\text { 引張荷重 } \\
(\mathrm{kN})\end{array}$ & $\begin{array}{l}\text { 硬さ } \\
\text { HRC }\end{array}$ & & & \\
\hline \multirow{2}{*}{ F10T } & \multirow{2}{*}{ M22 } & 120 & 303 & 1,030 & 1,078 & 19 & 330 & 31 & 27 & 40 & 0.132 \\
\hline & & 195 & 303 & 1,046 & 1,087 & 18 & 333 & 32 & 27 & 40 & 0.132 \\
\hline
\end{tabular}

として，表-4にブラスト処理面に関して，触針式表面粗 さ測定器により算出した，JSB0601で規定されている算 術平均粗さRaを示す．表面粗さの計測は，ボルト側及び ナット側の母板-連結板間の各接合面2面に対して行った. 継手長手方向については, ボルト列数3列の試験体の場合, ボルト間の2箇所で計測し, ボルト列数8列, 12列の場合, 最内・外縁ボルトとそのボルトに隣接するボルト間2箇所 ならびに継手方向中央位置の計3箇所（1面あたり）で計 測した. 文献11)ではブラスト処理に対して, $R a \geqq 10 \mu \mathrm{m} の$ 場合, すべり係数 0.45 を推奨しているが, 本試験体のRaは 全て $10 \mu \mathrm{m}$ 以上であった.

\section{(4) 組立て}

ボルトの締付けは，道示 IIに従って，内側から外側に 向かって順次行った. 締付け作業は 2 度に分けて行い, 1 次締めでは設計ボルト軸力の 60\%程度を導入し, 2 次締 めでは設計ボルト軸力の 100\%を導入した. 締付け軸力は 0\%増しせず設計軸力通りとした.ただし，計測側ですべ
るように，片側 (非計測側) は設計ボルト軸力の $120 \%$ 以 上で締付けを行い，非すべり側とした。

\section{3. 試験方法}

\section{(1) 試験概要と計測}

試験体組立て後に，ボルト軸力計測及びすべり耐力試 験を実施した。ボルト軸力計測では，ボルト軸力の経時 変化をひずみゲージにより計測した。すずり耐力試験で は，すべり挙動を把握するために，母板間及び母板-連結 板間の相対変位をクリップゲージにより計測するととも に，試験中のボルト軸力の変化を計測した.

図-2に計測箇所を示す。ボルトの軸力計測は，各試験体 3 体のうち 1 体のみ詳細に計測（詳細計測）し，それ以外 は計測点数を若干減らして計測（基本計測）した. ひずみ ゲージの貼付位置は，図-3に示すとおり，締付け厚の中央 に相当する位置とし，すべり後もボルト軸力を計測できる 


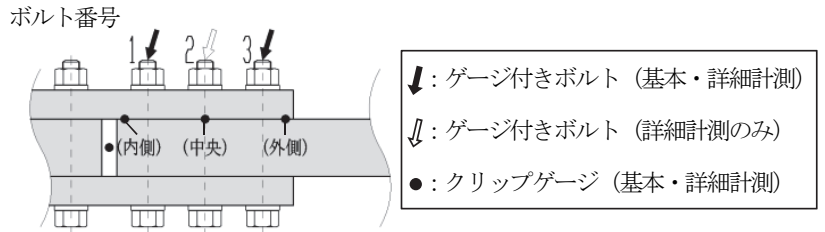

(a) 3列タイプ

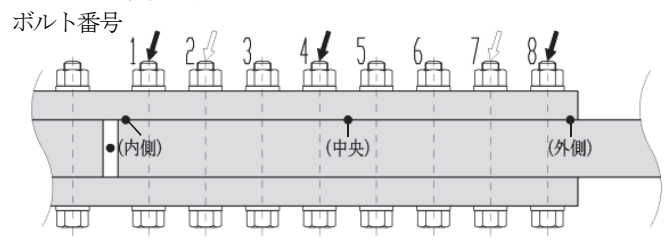

(b) 8列タイプ

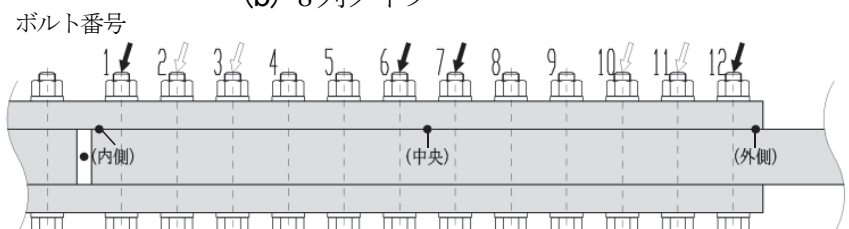

(c) 12列タイプ

図-2 ボルト軸力及び相対変位の計測箇所

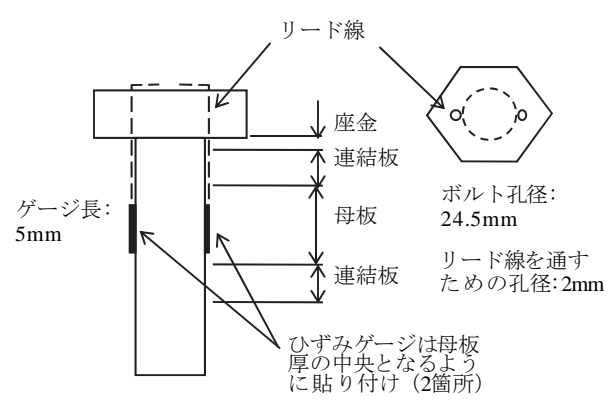

図-3 ボルトに対するひずみゲージの貼付位置

ようにボルト 1 本につき 2 箇所とした．また，母板間及び 母板-連結板間の相対変位の計測は, クリップゲージを用い て行い，詳細計測及び基本計測ともに同じ位置とした。

\section{（2）ボルト軸力計測}

すべり而力試験は締付け作業から 7 日以上経過した後に 行うこととし，試験体組立て後，７日間のボルト軸力の変 化をひずみゲージにより計測した，なお，本試験で使用し たひずみゲージのリード線はリード線自体の温度による 影響が軽微な 3 線式を使用している. 計測は最後のボルト 締付け完了後 6 時間までは5秒間隔で行い，6時間〜 7日間 までは1時間の間隔で行った.

\section{(3) すべり耐力試験}

すべり而力試験は，ボルト列数が 3列の試験体には土木 研究所所有の 載荷能力 $2 \mathrm{MN}$ の試験機を，8列及び 12 列の 試験体には載荷能力 30MN の試験機を使用した. 締付けか らすべり耐力試験実施までの期間は, 15〜30日であった.

試験では，試験体の両端部をチャックで固定して引張 荷重を作用させ, すべりが生じて荷重が低下した後, す心゙ りが生じた際と同程度の荷重に達するまで再載荷した。

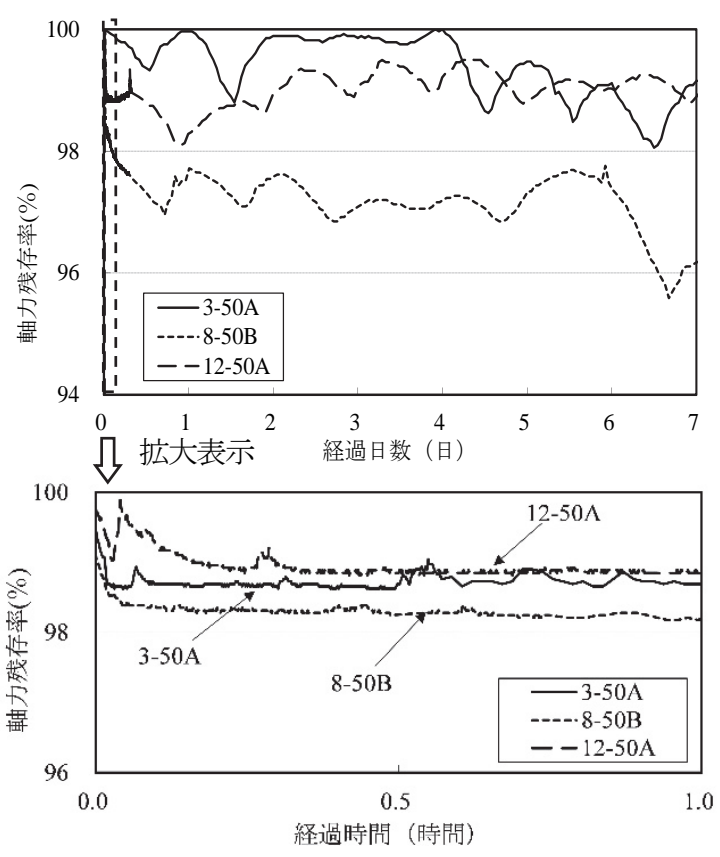

図-4 第 1 ボルト軸力残存率（締付後 7 日間経過後）の経時変化

載荷にあたって，2MN試験機では荷重制御（載荷開始時 $1 \mathrm{kN} / \mathrm{sec}$ ), $30 \mathrm{MN}$ 試験機では変位制御 (載荷開始時 $1.5 \mathrm{~mm} / \mathrm{min}$ ) とし, 荷重の増加に従って, 載荷速度を徐々に遅くし, 寸 ベり耐力を正確に計測できるように努めた.

なお，試験体 12-75Cについては，後述の式(2)のす心゙り 係数 $\mu_{0}$ が 0.38 であり,設計值 0.4 を若干下回る結果であっ た. 本試験結果については試験体の載荷装置へのセット アップ時の不具合がすべり荷重に影響を与えた可能性が あり，他の試験体と同等にすべり耐力の評価は行えない と判断し, 以下の分析では除外することとした.

\section{4. 試験結果}

\section{（1） ボルト軸力残存率（締付後 7 日間経過後）}

図-4に母板厚 $50 \mathrm{~mm}$ の各試験体から 1 体を抽出し，第 1 ボルト（図-2 参照）のボルト軸力の締付け後， 7 日間 における経時変化を示寸. 図中の縦軸は, 計測したボル 卜軸力をすべてのボルト締付け完了時の初期軸力で無 次元化した軸力残存率である. ボルト軸力の低下は締付 け直後に顕著にみられた. また, 別途計測した外気温の 変動の影響を受けて, ボルト軸力の経時的な变化がみら れた. 表-5に試験体ごとに計測対象ボルトの軸力残存率 （締付後 7 日間経過後）の平均值を整理した結果を示す。 全試験体で, 軸力残存率(締付後 7 日間経過後) は, 0.97〜 1.00 であり, ボルト列数, ボルト位置による軸力残存率 (締付後 7 日間経過後)の違いは明確にはみられなかっ た. 母板厚の軸力残存率への影響については 5. (1)で述 べる. 
表-5 ボルト軸力残存率（締付後 7 日間経過後）の平均值

\begin{tabular}{|c|c|c|c|c|c|c|c|}
\hline \multirow[b]{2}{*}{$\begin{array}{c}\text { 試験体 } \\
\text { No. }\end{array}$} & \multicolumn{3}{|c|}{ 構造諸元 } & \multicolumn{2}{|c|}{ ボル卜軸力 (kN) } & \multirow{2}{*}{\multicolumn{2}{|c|}{$\begin{array}{c}{[3]} \\
\text { 軸力残存率 } \\
\text { ( [2]/[1] })\end{array}$}} \\
\hline & $\begin{array}{c}\text { 母板厚 } \\
(\mathrm{mm})\end{array}$ & $\begin{array}{l}\text { 連結 } \\
\text { 板厚 } \\
(\mathrm{mm})\end{array}$ & $\begin{array}{l}\text { ボルト } \\
\text { 列数 }\end{array}$ & $\begin{array}{c}{[1]} \\
\text { 軸力 } \\
\text { 導入時 }\end{array}$ & $\begin{array}{c}\text { [2] } \\
\text { 7日間 } \\
\text { 経過後 }\end{array}$ & & \\
\hline $3-50 \mathrm{~A}$ & \multirow{9}{*}{50} & \multirow{9}{*}{26} & \multirow{3}{*}{3} & 207.4 & 207.0 & 1.00 & \multirow{3}{*}{0.99} \\
\hline 3-50B & & & & 207.5 & 205.6 & 0.99 & \\
\hline $3-50 C^{*}$ & & & & 205.9 & 203.7 & 0.99 & \\
\hline $8-50 \mathrm{~A}$ & & & \multirow{3}{*}{8} & 206.0 & 199.7 & 0.97 & \multirow{3}{*}{0.97} \\
\hline 8-50B & & & & 209.4 & 203.6 & 0.97 & \\
\hline $8-50 C^{*}$ & & & & 207.2 & 200.5 & 0.97 & \\
\hline $12-50 \mathrm{~A}$ & & & \multirow{3}{*}{12} & 209.4 & 207.5 & 0.99 & \multirow{3}{*}{0.99} \\
\hline 12-50B & & & & 207.2 & 203.1 & 0.98 & \\
\hline $12-50 C^{*}$ & & & & 205.6 & 202.9 & 0.99 & \\
\hline $3-75 \mathrm{~A}$ & \multirow{9}{*}{75} & \multirow{9}{*}{38} & \multirow{3}{*}{3} & 205.7 & 205.6 & 1.00 & \multirow{3}{*}{1.00} \\
\hline $3-75 B$ & & & & 207.8 & 209.2 & 1.01 & \\
\hline $3-75 C^{*}$ & & & & 206.0 & 206.9 & 1.00 & \\
\hline $8-75 \mathrm{~A}$ & & & \multirow{3}{*}{8} & 206.0 & 201.2 & 0.98 & \multirow{3}{*}{0.98} \\
\hline $8-75 B$ & & & & 205.6 & 202.5 & 0.98 & \\
\hline $8-75 C^{*}$ & & & & 205.5 & 201.1 & 0.98 & \\
\hline $12-75 \mathrm{~A}$ & & & \multirow{3}{*}{12} & 205.7 & 204.4 & 0.99 & \multirow{2}{*}{0.99} \\
\hline $12-75 \mathrm{~B}$ & & & & 205.4 & 203.5 & 0.99 & \\
\hline $12-75 C^{*}$ & & & & 206.5 & 205.0 & 0.99 & - \\
\hline
\end{tabular}

注) ※はボル卜軸力の詳細計測を実施 (図-2参照)

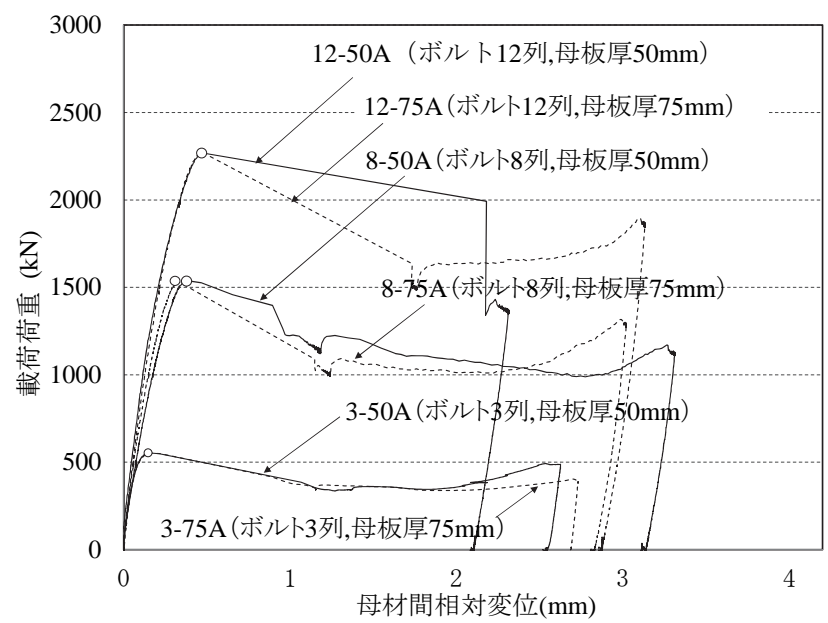

図-5 荷重-母板間の相対変位の関係

\section{(2) すべり耐力試験}

\section{a) 荷重と母板間の相対変位の関係}

図-5に各試験体のうち 1 体を例に，荷重と母板間の相 対変位の関係を示す．いずれの試験体においても，初期 は線形関係にあるが，徐々に相対変位が増加し勾配がゆ るやかになり，ピーク荷重を迎えた後，荷重の低下と相 対変位の急激な増加がみられる.これらの結果から，本 試験体はすべり先行型の挙動を呈していると推測される. ここでは, 荷重が増加しなくなり変位が急激に増加する 状態をすべりが生じた状態とし，この時の荷重值（図中 の曲線上の○印）をすべり耐力と定義した.

\section{b) すべり耐力及びすべり係数}

表-6に試験から得られた各試験体のすべり耐力及びす ベり係数を示す. 表中のすべり係数 $\mu_{0}, \mu_{2}$ は式(2), (3)に より算出した. すべり係数の設計值に対する評価は，設 計ボルト軸力により算出する $\mu_{0}$ を用いて行い，板厚，ボ ルト列数及び母板間の板厚差等の影響の分析については, 締付け完了時の軸力によって算出する $\mu_{2}$ を用いて行う.
表-6 すべり耐力及びすべり係数

\begin{tabular}{|c|c|c|c|c|c|c|c|c|c|c|c|}
\hline \multirow{3}{*}{$\begin{array}{l}\text { 試験体 } \\
\text { No. }\end{array}$} & \multicolumn{5}{|c|}{ 構造諸元 } & \multicolumn{6}{|c|}{ 試験結果 } \\
\hline & \multirow{2}{*}{$\begin{array}{c}\text { 母板 } \\
\text { 厚 } \\
(\mathrm{mm})\end{array}$} & \multirow{2}{*}{$\begin{array}{l}\text { 連結 } \\
\text { 板厚 } \\
(\mathrm{mm})\end{array}$} & \multirow{2}{*}{$\begin{array}{l}\text { ボルト } \\
\text { 列数 }\end{array}$} & \multirow{2}{*}{$\begin{array}{l}\text { 締付 } \\
\text { 軸力 } \\
\text { (kN) }\end{array}$} & \multirow{2}{*}{$\begin{array}{c}\text { 試験前 } \\
\text { 軸力 } \\
(\mathrm{kN})\end{array}$} & \multirow{2}{*}{$\begin{array}{l}\text { すべり } \\
\text { 耐力 } \\
\text { (kN) }\end{array}$} & \multicolumn{2}{|c|}{$\begin{array}{c}\text { すべり係数 } \\
\mu_{0}\end{array}$} & \multicolumn{2}{|c|}{$\begin{array}{c}\text { すべり係数 } \\
\mu_{2}\end{array}$} & \multirow{2}{*}{$\begin{array}{l}\text { 変動 } \\
\text { 倸数 }\end{array}$} \\
\hline & & & & & & & 各值 & 平均 & 各値 & 平均 & \\
\hline $3-50 \mathrm{~A}$ & \multirow{9}{*}{50} & \multirow{18}{*}{26} & \multirow{3}{*}{3} & 207.4 & 205.9 & 552 & 0.45 & \multirow{3}{*}{0.45} & 0.45 & \multirow{3}{*}{0.45} & \multirow{3}{*}{0.02} \\
\hline $3-50 \mathrm{~B}$ & & & & 207.5 & 202.3 & 560 & 0.46 & & 0.46 & & \\
\hline $3-50 \mathrm{C}$ & & & & 205.9 & 204.5 & 539 & 0.44 & & 0.44 & & \\
\hline $8-50 \mathrm{~A}$ & & & \multirow{3}{*}{8} & 206.0 & 195.2 & 1,537 & 0.47 & \multirow{3}{*}{0.48} & 0.49 & \multirow{3}{*}{0.49} & \multirow{3}{*}{0.03} \\
\hline $8-50 \mathrm{~B}$ & & & & 209.4 & 203.0 & 1,526 & 0.47 & & 0.47 & & \\
\hline $8-50 \mathrm{C}$ & & & & 207.2 & 201.7 & 1,612 & 0.49 & & 0.50 & & \\
\hline $12-50 \mathrm{~A}$ & & & \multirow{3}{*}{12} & 209.4 & 208.1 & 2,268 & 0.46 & \multirow{3}{*}{0.47} & 0.45 & \multirow{3}{*}{0.47} & \multirow{3}{*}{0.03} \\
\hline $12-50 \mathrm{~B}$ & & & & 207.2 & 200.9 & 2,259 & 0.46 & & 0.47 & & \\
\hline $12-50 \mathrm{C}$ & & & & 205.6 & 204.7 & 2,401 & 0.49 & & 0.49 & & \\
\hline $3-75 \mathrm{~A}$ & & & & 205.7 & 203.5 & 552 & 0.45 & \multirow{3}{*}{0.44} & 0.45 & \multirow{3}{*}{0.44} & \multirow{3}{*}{0.03} \\
\hline $3-75 \mathrm{~B}$ & & & 3 & 207.8 & 209.6 & 532 & 0.43 & & 0.42 & & \\
\hline $3-75 \mathrm{C}$ & & & & 206.0 & 208.4 & 548 & 0.45 & & 0.44 & & \\
\hline $8-75 \mathrm{~A}$ & & & & 206.0 & 201.2 & 1,532 & 0.47 & & 0.48 & & \\
\hline $8-75 \mathrm{~B}$ & 75 & & 8 & 205.6 & 203.3 & 1,667 & 0.51 & 0.48 & 0.51 & 0.49 & 0.04 \\
\hline $8-75 \mathrm{C}$ & & & & 205.5 & 204.8 & 1,540 & 0.47 & & 0.47 & & \\
\hline $12-75 \mathrm{~A}$ & & & & 205.7 & 202.5 & 2,261 & 0.46 & & 0.47 & & \\
\hline $12-75 \mathrm{~B}$ & & & 12 & 205.4 & 203.1 & 2,314 & 0.47 & 0.46 & 0.47 & 0.47 & 0.01 \\
\hline $12-75 \mathrm{C}$ & & & & 206.5 & 202.5 & 1,859 & 0.38 & - & 0.38 & - & - \\
\hline
\end{tabular}

$$
\begin{aligned}
& \mu_{0}=\frac{P}{n \cdot m \cdot N_{0}} \\
& \mu_{2}=\frac{P}{n \cdot m \cdot N_{2}}
\end{aligned}
$$

ここで,

$$
P: \text { すべり耐力 }(\mathrm{kN})
$$

$n:$ ボルト本数

$m:$ 接触面数 $(=2)$

$N_{0}:$ 設計軸力 $(=205 \mathrm{kN})$

$N_{2}$ : 試験前軸力（計測值） $(\mathrm{kN})$

試験体 12-75C を除く全試験体のすべり係数 $\mu_{0}$ は, 0.4 を上回っており，その平均值は 0.46 , 変動係数は各試験 体で $0.01 〜 0.04$ であった.

\section{c) 母板-連結板間の相対変位}

図-6にすべり耐力時（図-5に示す○印の時点）の母板 -連結板間の相対変位について, 試験体ごとに各 3 体の平 均值を整理した結果を示す。眓中には，クリップゲージ で計測した母板-連結板間の内側，中央，外側の相対変位 を示す.また，各試験体から 1 体を例に，図-7に荷重と 母材-連結板間の相対変位の関係を示す. なお，これらの 図ではボルト列数と板厚に着目して整理している.

ボルト列数に対して相対変位を比較すると（図6(a), (b)），3列の試験体では，内側，中央，外側において 差はほとんどみられないが，8列，12 列と多列になるに 伴い, 中央と端部 (内側, 外側) の差が大きくなってい る.また, 荷重と母材-連結板間の相対変位の関係におい て (図-7(a), (b))，内側と外側では，中央に比べ初期の段 階から相対変位が増加している. 寸なわち, ボルトが多 列配置となるにつれて，端部では荷重初期段階から局所 的にすべりが発生し，すべり発生荷重に至るまでには母 材-連結板間の相対変位について継手の中央と端部 (内側, 外側）を比べると差が著しくなり，継手内で不均一なす ベりが生じていると考えられる.

母板厚に対して相対変位を比較すると（図-6(c), 図 -7(c)），母板厚 $75 \mathrm{~mm}$ と $50 \mathrm{~mm}$ の場合では，すべり耐力 


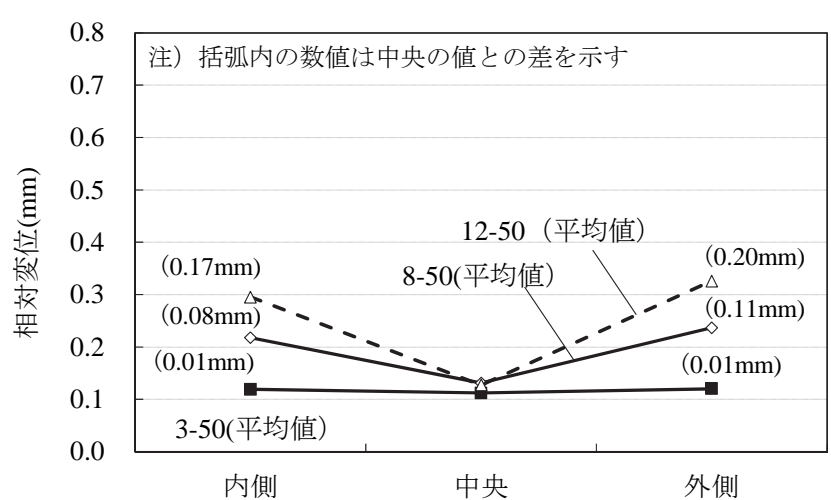

(a) ボルト列数による比較（母板厚 $50 \mathrm{~mm}$ )

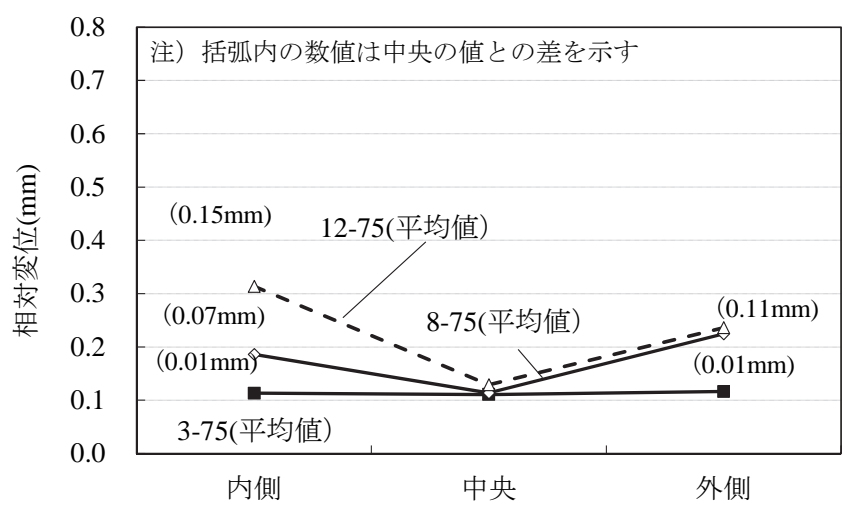

（b）ボルト列数による比較（母板厚 $75 \mathrm{~mm}$ )

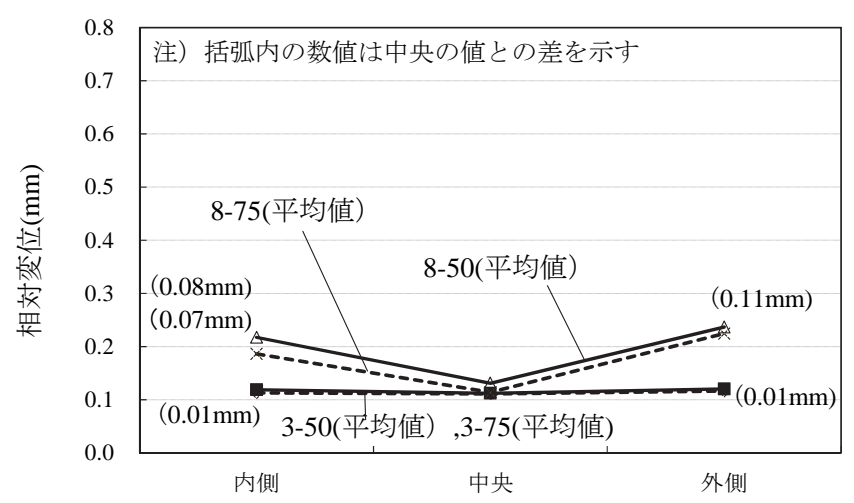

（c）母板厚による比較（ボルト 3列，8列）

図-6 すべり而力時の中央と端部の母板-連結板閒の相対変位

に至るまでの中央と端部の挙動や，すべり耐力時の差は 同程度であり，板厚による挙動の特筆すべき違いはみら れない。

\section{d) 試験時のボルト軸力の変化}

図-8に詳細計測を実施した試験体（12-75については, 基本計測を実施した試験体）における，試験時のボルト 軸力の変化を示す. 図中の括弧内の数值は, 試験開始時 （荷重 0kN時）のボルト軸力に対するすべり耐力時のボ ルト軸力の比率である. ボルト列数による中央と端部の 軸力減少の傾向に関して, 8列や12列の試験体にみられる ように，多列の場合には内側（ボルトNo.1）の方が軸力 の減少が若干大きい傾向が見られた．著者らによるす心゙ り挙動に関する解析的検討の,8)では，母板及び連結板に作 用する断面力の偏心から生じる付加曲げの影響による内

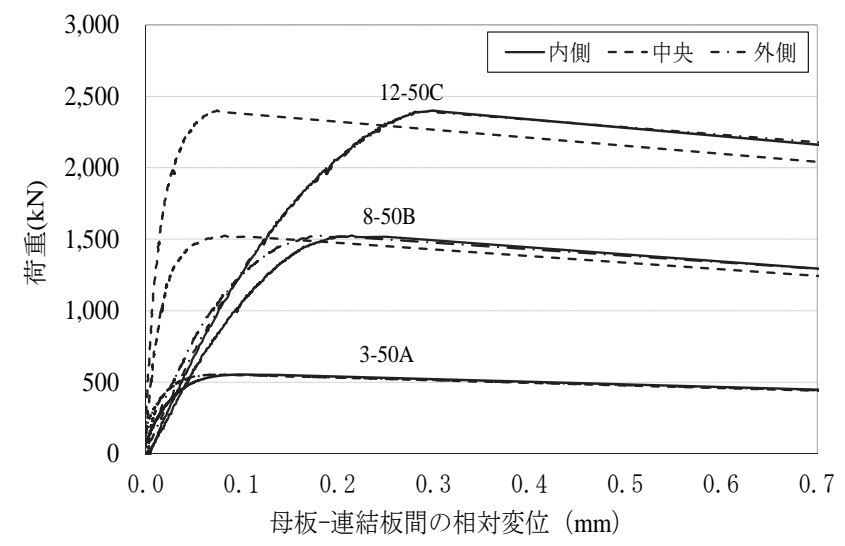

（a）ボルト列数による比較（母板厚 $50 \mathrm{~mm}$ )

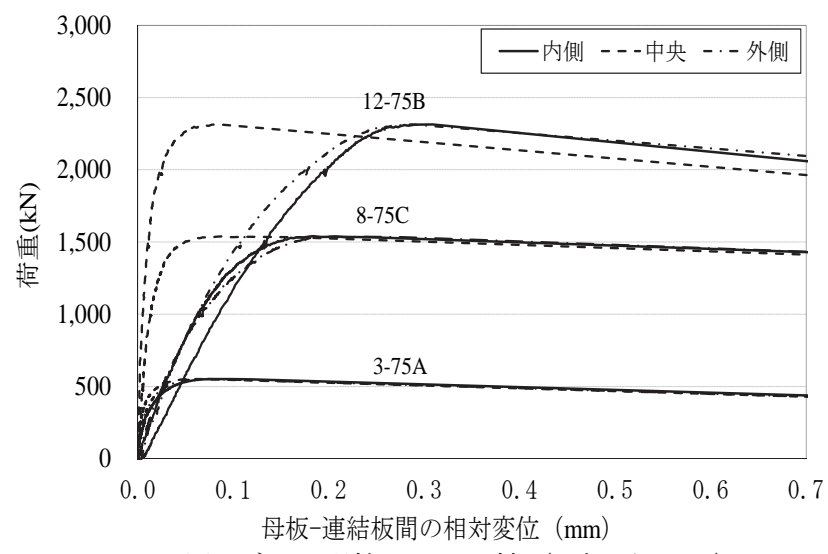

（b）ボルト列数による比較（母板厚 $75 \mathrm{~mm}$ )

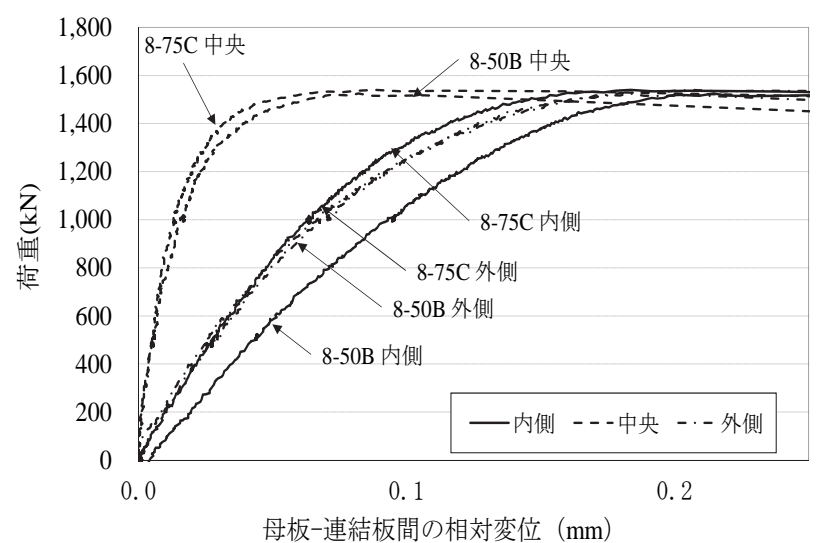

(c) 板厚による比較（ボルト列数 8 列）

図-7 荷重と母板-連結板間の相対変位の関係

側の軸力減少について明らかにしており，本試験結果も 同様の挙動によるものと考えられる.

ボルト軸力残存率と荷重の関係について, 試験体 12-75Aを例として図-9に示す．ボルト軸力に関しては内 側 (ボルト No.1) では荷重に対する低下の比率 (低下率) が大きく，試験開始時からすべり発生まで概ね一定の割 合で低下している。一方，中央（ボルトNo.6,7）ではボ ルト軸力の低下率は小さく，かつすべり直前に急激に低 下寸る挙動がみられる. 以上の傾向は 8 列や 12 列の全て の試験体で確認されており, 多列の場合の内側のボルト 軸力減少が顕著にみられた. 


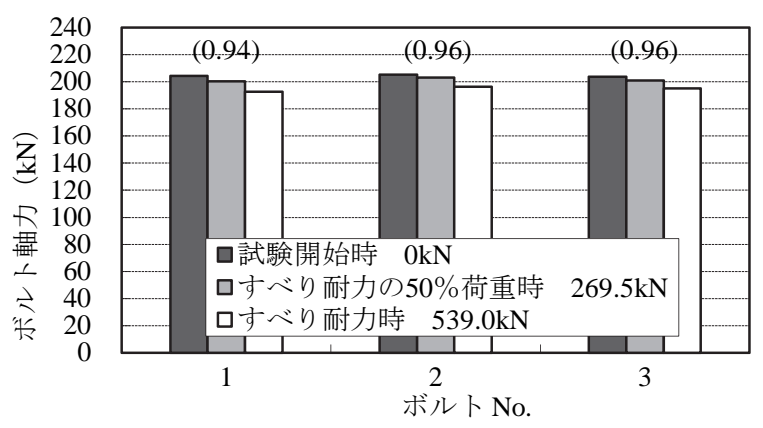

（a）試験体 3-50C（ボルト 3列，母板厚 50mm）

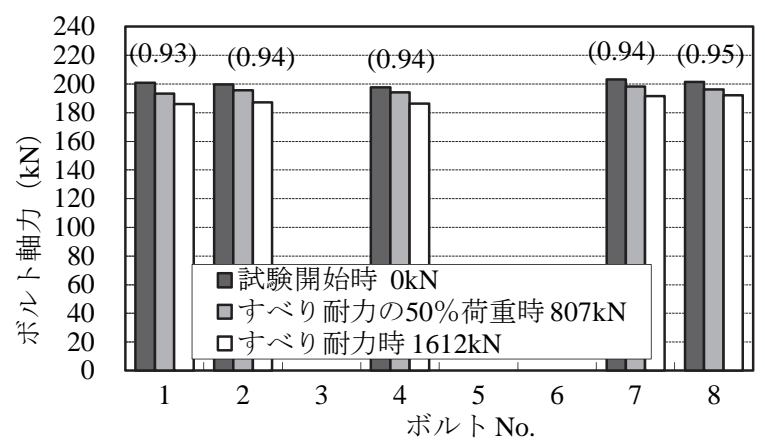

（c）試験体 8-50C（ボルト 8列，母板厚 50mm）

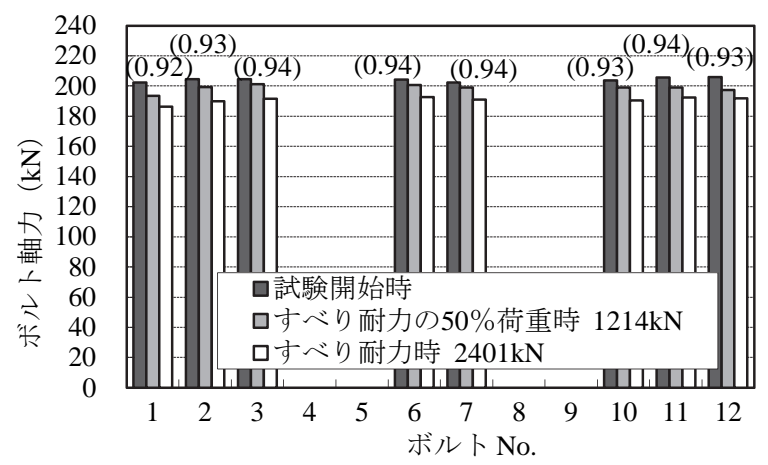

（e）試験体 $12-50 \mathrm{C}$ （ボルト 12 列，母板厚 50mm）

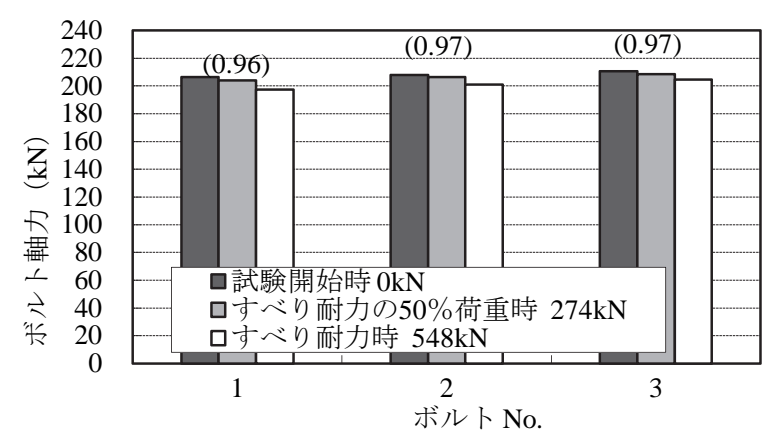

(b) 試験体 3-75C（ボルト 3列，母板厚 75mm）

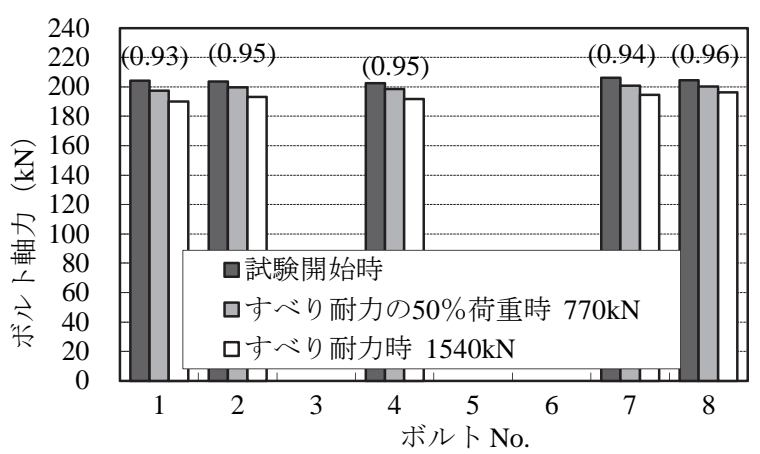

（d）試験体 8-75C（ボルト 8列，母板厚 75mm）

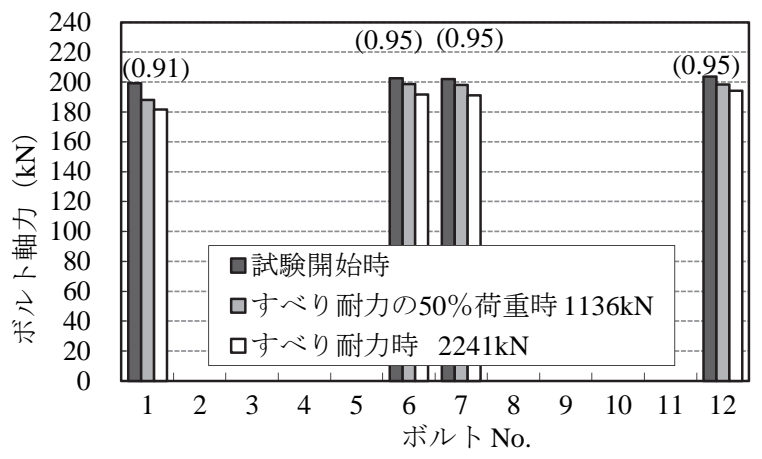

（f）試験体 12-75A（ボルト 12列，母板厚 75mm）

図-8 母板厚と各位置のボルト軸力残存率（すべり耐力時）の関係

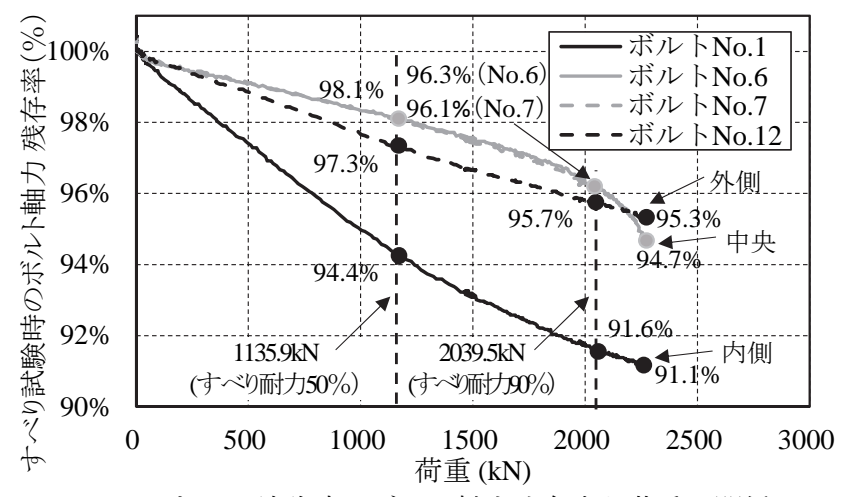

図-9 すべり試験時のボルト軸力残存率と荷重の関係 (試験体 12-75A)

\section{5. 母板厚, ボルト列数の影響}

本章では，母板厚及びボルト列数が継手挙動に与える 影響について，ボルト軸力導入後の経時変化（ボルト軸
力残存率）と，す心゙り係数 $\mu_{2}$ に着目して考察する.

\section{(1) 母板厚の影響}

図-10 に母板厚とボルト締め付け時から 7 日後のボル 卜軸力残存率の関係を示寸．ボル卜軸力の変化に関して 板厚による違いは小さいが，板厚 $75 \mathrm{~mm}$ の方が軸力残存 率が若干大きい. 連結部が厚くなるとボルト長が長くな り, ボルト長が長いほど軸力残存率が大きくなる傾向は, 文献 12)においても無機ジンクリッチペイント仕様の接 触面処理の場合に対して報告されている. 同文献で考察 されているように, 締付け厚に含まれるボルトのねじ部 長さが主に影響しているものと考えられる.

図-11に母板厚とすべり係数 $\mu_{2}$ の関係を示す. すべり 係数 $\mu_{2}$ は板厚によらずほぼ一定であり, 母板厚 $50 \mathrm{~mm}$ と $75 \mathrm{~mm}$ との間では, 板厚による違いは明確にみられな い. 


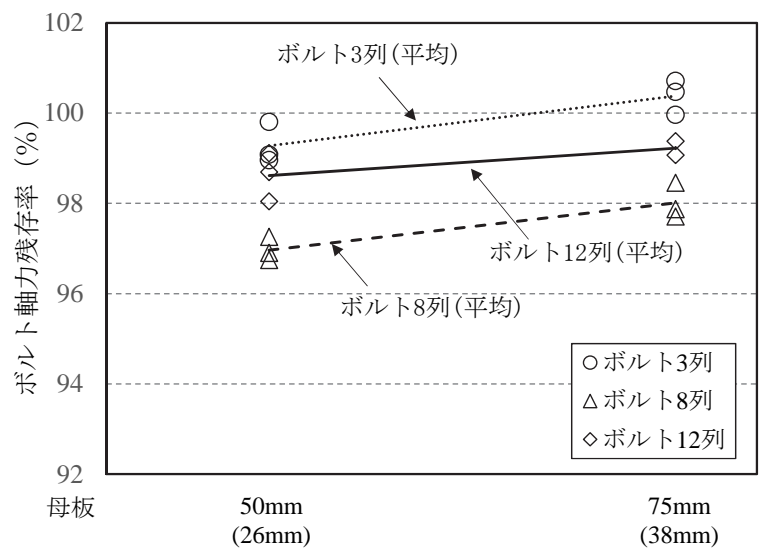

図-10 母板厚とボルト軸力残存率 (試験前) の関係

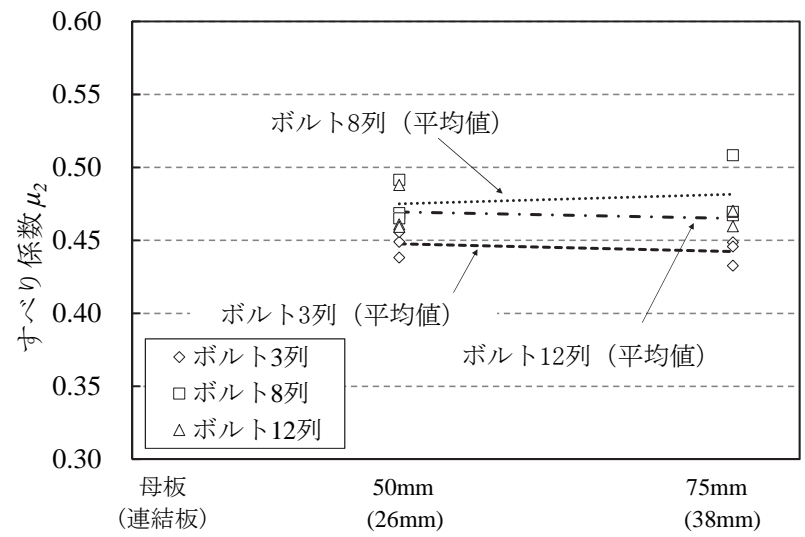

図-11 母板厚とすべり係数 $\mu_{2}$ の関係

\section{（2） ボルト列数の影響}

図-12 にボルト列数とすべり耐力比の関係を示す。こ こで，すべり耐力比とは，各試験体のすべり係数 $\mu_{2}$ の 8 列試験体の寸べり係数 $\mu_{2}$ (平均值) に対する比を表す. ボルト列数が 8 列から 12 列に増加すると, 8 列の場合と 比較してすべり耐力は母板厚 $50 \mathrm{~mm}, 75 \mathrm{~mm}$ ともに約 3\% 低下している．また，図中には，道示 II ${ }^{9}$ 解説中のボル 卜列数 12 列に対する低減係数 (無機ジンクリッチペイン 卜仕様）の 0.92 より求めたすべり耐力比を示し，本試験 のすべり係数の低下程度は, この值よりもさらに小さい 傾向にある.

なお，ボル卜列数 3 列の試験体では, 8列に比べてすべ り係数が小さくなっており，同様の傾向は著者らによる 文献6)，7) においても報告されている。，一般に，母板間 の板厚差や母板及び連結板端部の凹凸等の初期不整に対 して，母板と連結板はボルト軸力によって弾性変形して 密着しようとするが，板厚が厚いと剛性が大きく，初期 不整の影響を受けやすくなる，すなわち，導入された軸 力の一部は板の弾性変形に使われ，接触圧が減少するこ とになるが，列数が多くなると，ボルト一本あたりの初 期不整の影響が小さくなり，結果としてすべり係数に与 える影響が相対的に小さくなっているものと考えられる.

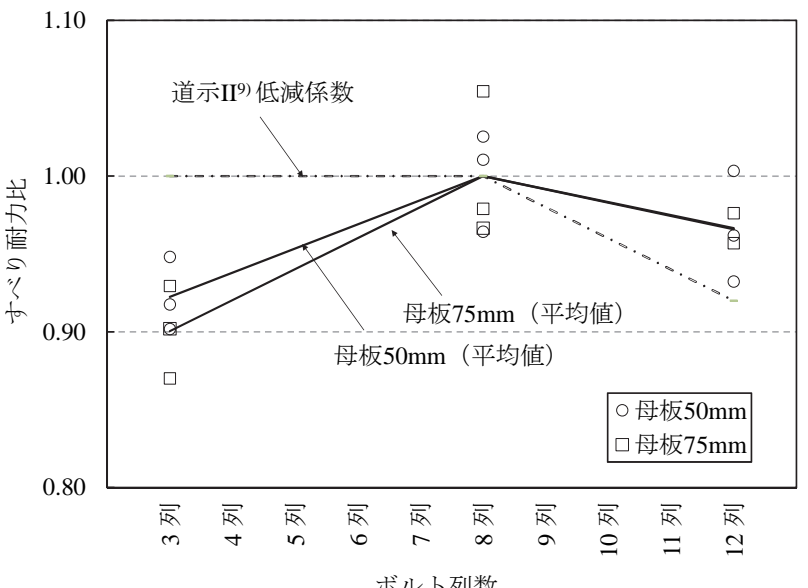

図-12 ボルト列数とすべり耐力比の関係

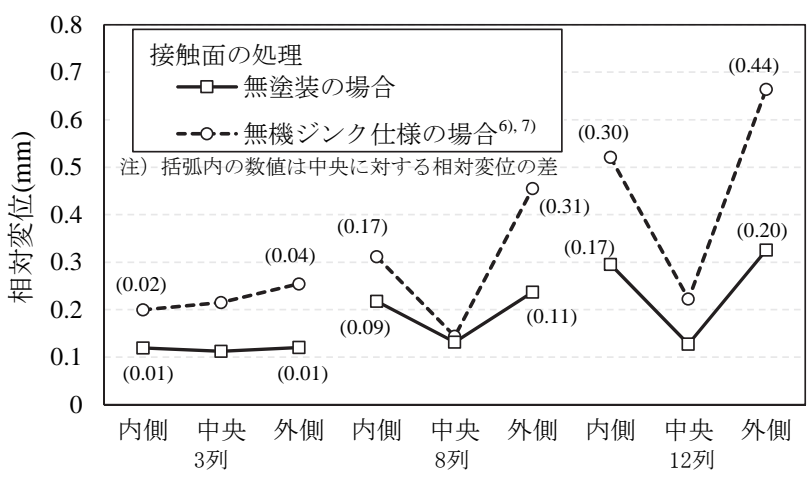

(a) 母板厚 $50 \mathrm{~mm}$

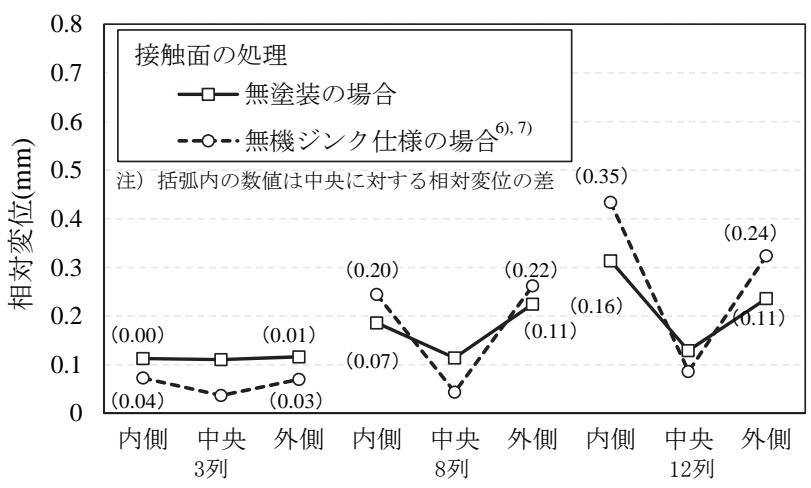

(b) 母板厚 $75 \mathrm{~mm}$

図-13 すべり而力時の母板-連結板間の相対変位の比較

\section{6. 既往の試験結果との比較}

著者らは, 本試験を実施する前に, 本試験体を使用し, 接触面に無機ジンクリッチペイント (以下, 無機ジンク) を塗布した場合に対して，同様のすべり耐力試験の,》を実 施している．図-13にすべり耐力時の母板-連結板間の相 対変位について，本試験結果（無塗装の場合）と無機ジ ンクを塗布した場合の試験結果を比較して示寸，接触面 の処理によらず，中央に対する端部（外側，内側）の相 対変位の差は, ボルト列数の増加に伴い, 大きくなる傾 向がみられる．なお，無機ジンクを塗布した場合の方が すべり係数が大きいため, 同一の板厚, ボルト列数では, 


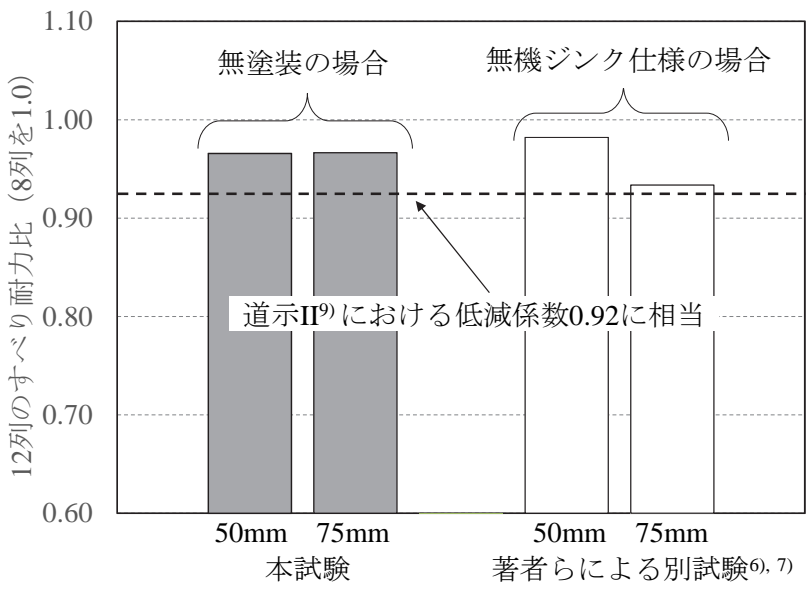

図-14 8列に対する 12 列のすべり耐力比の無機ジンク仕様の 試験結果との比較

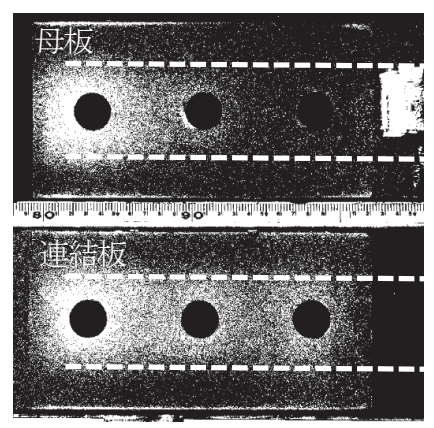

(a) 本試験結果 (無塗装)

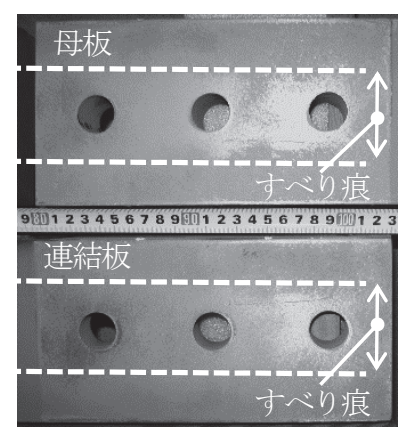

(b) 無機ジンクを塗布した 場合 6),7
図-15 すべり発生時におけるすべり面の状況

塗装の場合より無機ジンクの場合の相対変位は大きく なっている.

図-14にボルト列数8列に対する12列の各板厚における すべり耐力比について，本試験結果と接触面に無機ジン クを塗布した場合の試験結果を比較して示す．参考に, 図中には無機ジンク仕様の場合の低減係数に相当するす ベり耐力比を示す．いずれの場合も，12列では低減係数 の範囲内のすべり耐力の低下がみられる.

図-15に試験後の母板及び連結板の接触面の状況（ボル 卜列数3列で, 母板厚 $50 \mathrm{~mm}$ の試験体の例) を示す. なお, 本試験結果（無塗装の場合）の写真については，すべり 面を明確にするため画像の強調処理を行っている. 板幅 方向のすべり発生面の状況に着目すると, 接触面の処理 によらず同程度の幅のすべり痕が生じていることが確認 できる.

\section{7. まとめ}

本検討では，接触面を無塗装とした高力ボルト摩擦接 合継手を対象に, 板厚 $(50,75 \mathrm{~mm})$, ボル卜列数 (3, 8, 12列) をパラメータとした試験体のすべり耐力試験を行 い，母板厚及びボルト列数が継手挙動に及ぼす影響につ
いて検討した. 得られた主な結果を以下にまとめる.

（1）設計ボルト軸力に対するすべり係数 $\mu_{0}$ は $0.43 \sim 0.51$ （平均值 0.46）であり，道示 II に規定されるすべり 係数 0.4 を上回った.

（2）母板厚の影響に関して，母板厚 $50 \mathrm{~mm}$ と $75 \mathrm{~mm}$ では すべり係数 $\mu_{2}$ (各試験体の平均值) の違いはほとん ど見られなかった。

（3）ボルト列数の影響に関して，ボルト列数 8 列に対す る 12 列の場合のすべり係数 $\mu_{2}$ （各試験体の平均值） は，母板厚 $50 \mathrm{~mm}, 75 \mathrm{~mm}$ ともに約 3\%低下した。

(4) すべり耐力時の母板と連結板間の相対変位に関し て, 8列及び 12 列の場合, 継手の中央と端部 (内側, 外側）ではすべり発生荷重に至るまでに差が大きく なる挙動が確認され, 端部で作用力が大きくなる傾 向にあることが，すべり係数の低下に影響を及ぼし たと考えられる.

(5) ボルト列数の多列化によるすべり係数の低下の傾向, すべり耐力時の継手内の相対変位の不均一さ及び すべり面の発生の傾向は，著者ら の,7が同一試験体 を用いて別途実施した，接触面に無機ジンクリッチ ペイントを塗布した場合のすベり耐力試験の結果 と概ね一致していた。

今回の試験結果を踏まえ, 接触面を無塗装とした高力 ボルト摩擦接合継手に対して, 多列の場合のボルト許容 力に乗じる低減係数について検討する予定である.

\section{参考文献}

1) 佐伯彰一, 西川和廣, 滝沢晃 : 高力ボルト摩擦接合継 手に関する試験調査 (I) 引張荷重を受ける継手のす心゙ り耐力, 土木研究所資料，第 1871 号，1982.9.

2) (社) 日本道路協会 : 道路橋示方書 - 同解説 II 鋼橋編, 1980.2.

3) 山口隆司, 彭雪, 鈴木康夫, 宮尾修平 : 極厚鋼板を対 象とした多列高力ボルト摩擦接合継手の力学的挙動 に関する実験的研究, 鋼構造論文集, 第 17 巻, 第 66 号, pp.23-33, 2010.6.

4) 馬場賢三, 田島二郎, 平野茂 : 太径多列高力ボルト摩 擦継手試験, 橋梁と基礎, pp.8-14, 1985.10.

5) 玉越隆史, 大久保雅憲, 池田秀継, 加藤浩一：国土技 術政策総合研究所資料, 第 624 号, 平成 21 年度道路 調查費等年度報告, pp.104-105, 2011.2.

6) 村越潤, 遠山直樹, 梁取直樹, 澤田守, 大获敦郎, 石 澤俊希, 山口隆司: 高力ボル卜摩擦接合継手の設計法 の合理化に関する共同研究報告書, 共同研究報告書, 第 428 号， 2012.1 .

7) 村越潤, 澤田守, 山口隆司, 彭雪, 大猚敦郎 : 接触面 に無機ジンクリッチペイントを塗布した厚板・多列の 高力ボルト摩擦接合継手のすべり耐力試験, 土木学会 論文集 A1，Vol.70，No.1，pp.94-104，2014.3.

8) 彭雪, 山口隆司, 高井俊和, 村越潤, 澤田守 : 厚板多 列高力ボルト摩擦接合継手の構造諸元がすべり挙動 に与える影響に関する解析的研究, 土木学会論文集 A1, Vol.69, No.3, pp.452-466, 2013.9. 
9) (社)日本道路協会 : 道路橋示方書 - 同解説 II 鋼橋編, 2014.3.

10) 西村宣男, 秋山寿行, 亀井義典 : 高力ボルト摩擦接合 継手に関する最近の研究動向, 土木学会論文集, No.675/I-55, pp.1-14, 2001.4.

11) (社)土木学会 : 高力ボルト摩擦接合継手の設計・施工・ 維持管理指針(案), p.36, 2006.11.
12) 南邦明, 森猛, 堀川秀信 : $50 \mathrm{~mm}$ 厚板鋼板を用いた太 径ボルト(M36)継手のすべり耐力試験, 土木学会論文 集 A, Vol.62, No.2, pp.267-278, 2006.4.

(2015. 6. 1 受付)

\title{
SLIP RESISTANCE TESTS OF FRICTION-TYPE HIGH-STRENGTH MULTI BOLTED JOINTS WITH UNCOATED CONTACT SURFACES ON THICK PLATE
}

\author{
Jun MURAKOSHI, Daisaku ISHIHARA, Mamoru SAWADA \\ and Takashi YAMAGUCHI
}

In this paper, influence of number of rows of bolts and plate thickness on slip resistance is discussed based on the slip resistance tests. The slip resistance tests of high strength bolted friction type joints with uncoated contact surfaces were carried out for the test specimens which have combinations of 50/75mm thickness plates and 3/8/12 rows of bolts. As a result of these tests, it was observed that all the specimens had slip coefficients over 0.4 which is specified in the current deign code, Japanese Specification for Highway Bridges, and it is found that the slip resistance of the 12-row-specimens decreased approximately $3 \%$ compared with 8-row-specimens. 